\title{
Apocrine Hidrocystoma of the Cheek
}

\author{
Kruse AL, Zwahlen R, Bredell MG, Riener MO, Grätz KW \\ University Hospital Zurich, ${ }^{1}$ Department of Craniomaxillofacial and Oral Surgery, \\ ${ }^{2}$ Department of Pathology
}

A 63 year old male patient was referred to the outpatient station of the Department of Craniomaxillofacial and Oral Surgery of the University Hospital Zurich with a 5-year history of a painless swelling of the right cheek without any progression or drainage. There was no history of trauma. Medical and family histories were inconspicuous.

The physical examination showed a mass measuring $2 x 2 \mathrm{~cm}$ on his right cheek. The overlying skin presented intact despite the centre of the mass presented dark coloured. Fluctuation could be elicited on bimanual palpation. The facial and trigeminal nerve functions were normal. Clinically no palpable lymph nodes in any level of the neck were detected (Figure 1). An exocrine tumor or unlikely a melanoma were considered to be differential diagnoses.

Sonographically a well-circumscribed cystic lesion measuring 1.3 x $0.5 \mathrm{~cm}$ was discovered, connected with the overlying skin. However, there was no connection with the parotid gland or with any other adjacent structure.

The analysis of the fine needle aspiration revealed a brown, clear fluid without any malignant cells or epithelial cell elements (Figure 2).

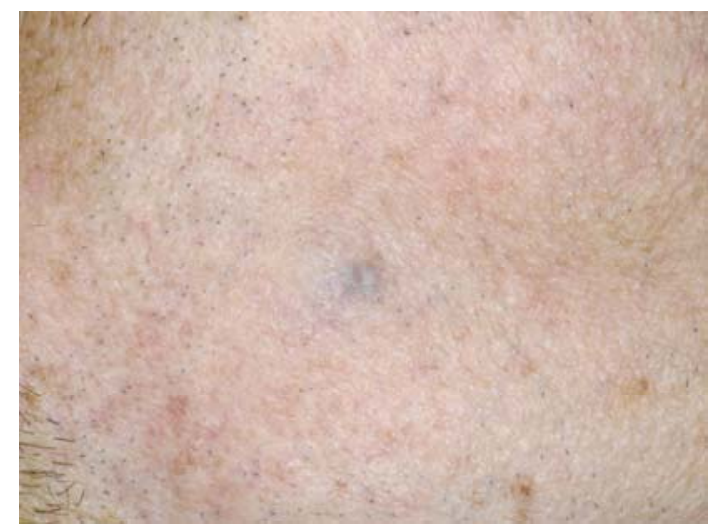

Figure 1

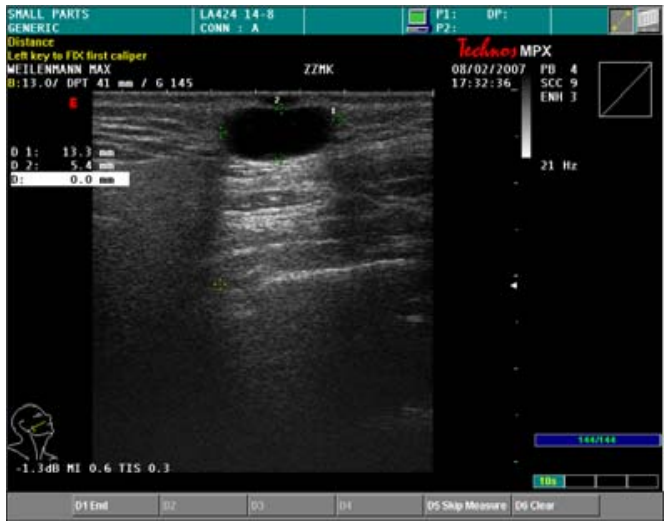

Figure 2 
The excision was performed under general anaesthesia. After an ellipsoidal skin incision at the top of the cystic lesion, its dissection from the adjacent structures was easy to perform by blunt dissection due to its well circumscribed boundaries.

The histopathological analysis detected a multilocular cystic lesion within the dermal layer of the skin (Figure 3). The cysts were lined by an outer layer of flattened myoepithelial cells and an inner layer of tall columnar cells with an eosinophilic cytoplasm and basally located nuclei (Figure 4). Therefore pathologically the lesion was determined to be an apocrine hidrocystoma.

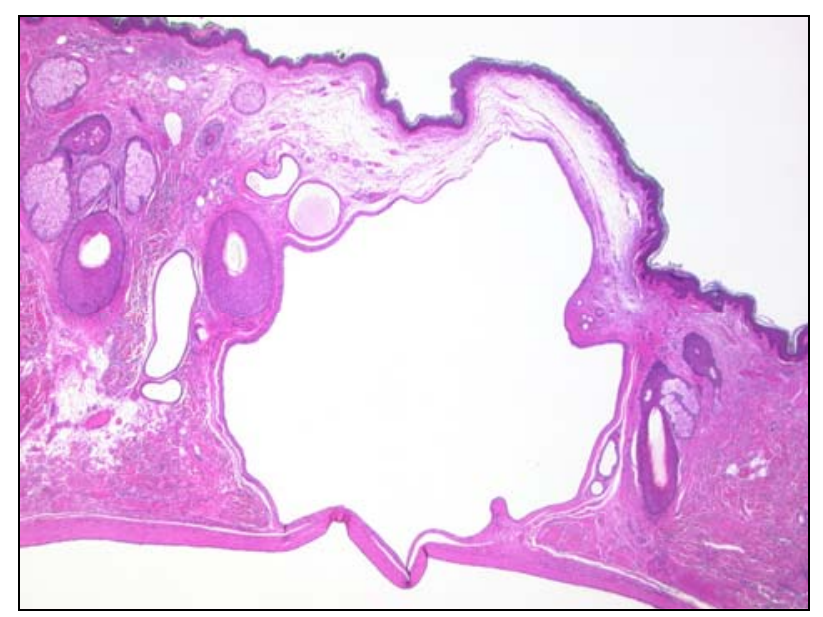

Figure 3: Overview of the apocrine hidrocystoma with a multilocular cystic space within the dermal layer of the skin (H\&E, x12.5)

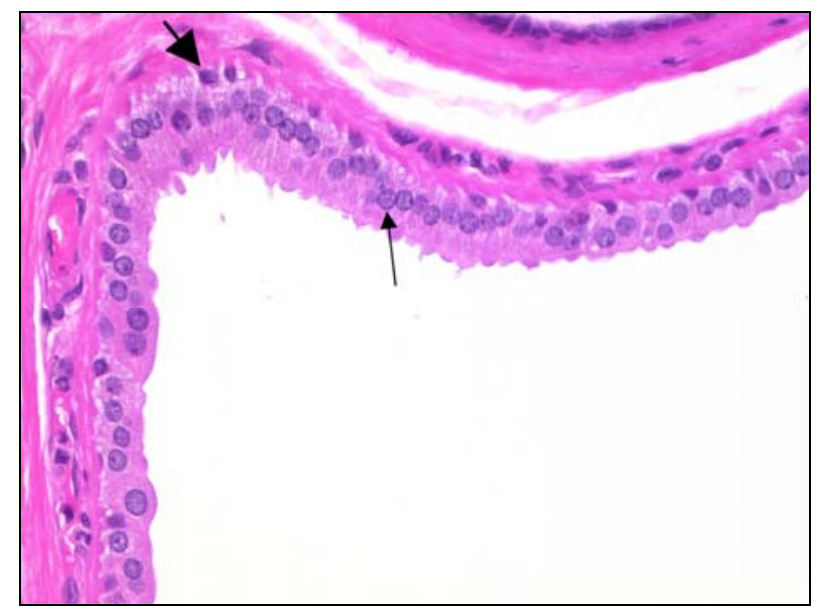

Figure 4: Lining of the cysts with an inner layer (thin arrow) of apocrine cells and an outer layer (thick arrow) of myoepithelial cells (H\&E, x200) 


\section{Discussion}

Apocrine hidrocystoma is an uncommon benign cystic proliferation of the apocrine sweat glands. Usually it presents as a slow growing, uni- or multilocular lesion. Their participation in the rare inherited Schöpf-Schulz-Passarge syndrome has been described already elsewhere (Alessi $E$ et al.). In general they present asymptomatic. Whereas the axilla and the periorbital region are considered to be the most common sites of origin of apocrine hidrocystomas, apocrine glands are usually located in the axilla, perineurium and nipples and only a few of them uncommonly may be located in the facial area (Anderson et al.).

Syringoma, malignant melanoma as well as follicular cysts have to be considered as differential diagnoses.

According to the possibilities of therapy, different techniques have been discussed (surgical excision, cryotherapy, electro dissection and laser treatment): Echague $A V$ et al., ..., used a 1450nm Diode Laser in multiple small hidrocystoma of the face in order to prevent scaring. This technique provided good results, whereas other areas on the cheek showed only little or no improvement, when treated with photodynamic therapy. Also Del Pozo J et al.,..., treated multiple apocrine hidrocystomas successfully by using a carbon dioxide laser. Gupta $S$ et al.,..., suggested that lesions less than $1 \mathrm{~cm}$ in diameter should be treated with electro dissection and lesions exceeding this dimension with excision.

In the here presented case we decided to perform an excision due to the size of the lesion. The postoperative healing turned out to be uneventful. Up to now, to the authors' knowledge the lesion did not recur. 


\section{References}

1. Alessi E, Gianotti R, Coggi A: Multiple apocrine hidrocystomas of the eylids.Br J Dermatol. 1997 Oct;137(4):642-5.

2. Anderson PJ: Apocrine Hydrocysadenoma of the Ear. Otolaryngol Head Neck Surg (2005) 133; 981-982.

3. Anzai S, Goto M, Fujiwara S, Da T: Apocrine hidrocystoma: a case report and analysis of 167 Japanese cases. Int J Dermatol. 2005 Aug; 44(8): 702-3.

4. Del Pozo J, Garcia-Silva J, Pena-Penabad C, Fonseca E: Multiple apocrine hidrocystomas: treatment with carbon dioxide laser vaporization. J Dermatol Treat. 2001 Jun, 12(2):97100.

5. Echague AV, Astner S, Chen AA, Anderson RR: Multiple apocrine hidrocystoma of the face treated with a 1450-nm diode laser. Arch Dermatol. 2005 Nov; 141(11):1365-7.

6. Gkolfinopoulos T, Ingen-Housz-Oro S, Cavelier-Balloy B, Blanchet-Bardon C: SchopfSchulz-Passarge syndrome: 2 cases. Ann Dermatol Venereol. 2001 Dec;128(12):1330-3.

7. Gupta S, Handa U, Handa S, Mohan H: The efficacy of electrosurgery and excison in treating patients with multiple apocrine hidrocystomas.

8. Mallaiah U, Dickinson J: Photo essay: bilateral multiple eyelid aporine hidrocystomas and ectodermal dysplasia. Arch Ophthalmol. 2001 Dec; 119(12):1866-7.

9. Santos-Juanes J, Galache Osuna C, Sanchez Del Rio J, Soto de Delas J, Requena L: Apocrine hidrocystoma on the tip of a finger. Br J Dermatol. 2005 Feb;152(2):379-80.

10. Schleich SM: Multiple translucent facial papules. Apocrine hidrocystoma. Arch Dermatol. 1998 Dec; 134(12): 1627-8, 1630-1. 